period in the person of a certain Pascalis Romanus, who also shared the interest in signs and wonders which prevailed at Manuel's court. His Liber thesauri occulti, with an introduction citing Aristotle's De naturis animalium, Hippocrates, and 'Cato noster', is a dream-book compiled at Constantinople in $1165 .{ }^{20}$

Charres H. Haskers.

\title{
Provincial Priors and Vicars of the English Dominicans
}

A FEW additions and corrections may be made to Father Gumbley's list published in this Roview, above, pp. 243-51. Some of the notes here given were printed in my edition of the Durham Liber Exemplorum (British Society of Franciscan Studies, vol. i, 1908), p. 135, in connexion with Simon of Binton.

A. G. LTTTLE.

Simon of Hinton, Henton, or Heynton, is said to have been provincial c. 1360. The authority is Bale. The Durhsm Liber Exomplorum, written between 1270 and 1279, quotes a story about a clerious lubricus and adds: ' Hoc autem exemplum scripserat in libro suo quidam frater noster qui de fratre Symone de Heynton materiam (?) sudierat.' In the catalogue of the library of 'Christchurch, Canterbury, drewn up when Eestry was prior (1284-1331), occurs' the entry 'Compilaciones fratris Symonis de Hentun '. 1 The only manuscript containing works by Simon of Hinton that I know of (New College 45) is dated by Core, ' sec. riv ex.'. A theological miscellany in Hart. MS. 2316 quotes a story from Simon: 'Narravit frater Simon de Henton in leccione sus' (fol. 58), but this manuscript also is of the second half of the fourteenth century. It is, however, clear from the evidence that Simon of Hinton flourished in the thirteenth centary, and there is little doubt that he is to be identified with the Simon who was provincial prior from 1254 to 1261 . Bale has put him a century too late.

Some of the gaps after Hugh Dutton, elected provincial in 1339 or 1340 , may be filled ap from the public records and episcopel registers.

1346, 1347. Arnold de Strelly or Strelley as provincial prior presented friars to hear confessions : Hereford Episcopal Registers, Trillek, pp: 92, 104.

1350, 1351-3. Gregory of St. Michael as provincial presented friars to hear confessions: Bath \& Wells Episcopal Registers; Red. de Salopis (Bomerset Record Society, x), p. 639 ; Hereford Episcopal Registers, Trillek, pp. 19, 20.

20 'Incipit liber thesenri occulti a Pascalo Romano oditus Constantinopolis anno mundi .ti de Lriiii, sno Christi .m.c.lor. Theseuru ocenitus roquicecit in corde aspientil ... succincto ad thesurum desiderebilem eperiondum properemus. Som'pnimm itequo ent figurs', sco: Digby MSS. 103, If 41-58 v, proceding I00's Omeiracriticon. Tho fint of the two books of the treaties is also in the Britiah Mrosem, Harleian MS. 1025, \pm 1.

-1 II. R. James, The Ancient Libraries of Canterbury and Dower, p. 71. 
1356, 1357, 1361. John de Tatenhall, D.D., appears as provincial in these years : Heroford Episcopal Registers, Charlton, p. 61 ; Cal. of Papal Petilions, i. 370.

1364. Robert Pynke : Cal. of Letter Books of the City of London, G, p. 177 ; Sharpe, Wins, ii. 36.

1368, 1370. William of Bottisham or Bodekisham presented friars to Bishop Chariton in 1368 (Reg., p. 47), and isoned letters of fraternity at the chapter of Iincoln in the same year (Poblic Becord Office, Anc. Deeds, A 13187): he was concerned in the arrest of an apostate friar in 1370 (Public Record Office, Chancery Warrants, file 1765, no. 4).

1371-2. Thomas Rashook, called Thomas Vichor in the Acts of the General Chapters, was, according to the Acts of the General Chapter held at Carcsseonne in 1378, deposed by the Master-Ceneral six years ago, i. e. in 1372 (Acta, ii. 450-1)2: He must therefore have been elected provincisl before that, probsbly in 1370 or 1371 .

1373, 1374. Nicholas de Monington appesrs as provincial in September 1373 and March 1373-4 (Public Record Office, Chancery Warrants, file 1751, nos. 5 and 6).

1374 (?)-1382. Thomss Rushook or Vichor does not seem to have recognized the validity of his deposition, as he was again declared depased by the General Chapter in 1378 (Acta, ii. 451), and several vicars were appointed. But in 1379 Urban VI annulled all proceedings against Thomas Rushook and declared him to have been and to be provincial of England (Cal. of Papal Letters, v. 14-15). He resigned in 1382 on becoming archdeacon of St. Asaph. The General Chapter which adhered to Avignon

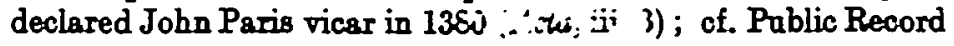
Office, Anc. Petitions, 6666).

1404 (?). John Dille appears as provincial in Public Record Office, Chancery Miscell., bundle 19, file 4, no. 11. The document containg articles of John Dille against John Cliderowe, chaplain, praying that the latter may be restrained from majntaining the prioress and sisters of Dartford against their ordinaries. It is not dated, but appears to belong to the end of the fourteenth or beginning of the fifteenth century. Perhaps John Dille should be inserted between William Pikworth and John of Lancaster.

1422. Thomas Waryn was provincial prior on 22 January 1422 (Stowe Chsrters; no. 605, British Museum). As John of Rodesdale was provincial prior on 7 Febrasry 1422, it is probable that one of these years should be 1423. (John of Redesdale's grant to Richard of Barton is to be found in Public Record Office, Excheq. K. B., Eccles., 6/47.)

1462. John appears as provincial prior in British Musenm, Add. Charters, 17136.

\footnotetext{
- 'Quis r. p. trator Elias magister ordinis ax officio sco provinoiam Anglie dudum anno serto proterito viaiteverit,' se. I haro not found eny allusion in the Englieh Pablio Records to this visitetion. It is alear from an entry in the Close Rolls, 23 Xag 1377, thet Elies was in Englend at that date.
}

vOL. $\times \times x m$. -NO. CXXXCh. 